\title{
AS CONTROVÉRSIAS A RESPEITO DO PRAZO E DO TEMPO RAZOÁVEIS NA BUSCA DA SOLUÇÃo DE MÉRITO À LUZ DO CÓDIGO DE PROCESSO CIVIL DE 2015
}

THE CONTROVERSIES REGARDING THE TIME LIMIT AND REASONABLE TIMING IN THE PURSUIT OF THE MERIT SOLUTION IN THE LIGHT OF THE 2015 CIVIL PROCEDURE CODE

Maria Rafaela Junqueira Bruno RODRIGUES ${ }^{1}$

William Vinicius Machado TRISTÃO

ISSUE DOI: $10.21207 / 1983.4225 .723$

\footnotetext{
${ }^{1}$ Pós-Doutorado em Direito e Saúde na Università Degli Studi Di Messina - Itália (2014/2015). Doutorado em Direito pela Uni-versidade do Vale do Rio dos Sinos (2006). Graduação em Direito pela Faculdade de Direito de Franca (1991), Especialização em Metodologia do Ensino Superior (2001), Mestrado em Direito pela Universidade de Franca (2000), Especialização em Psicanálise Contemporânea (2006), Aperfeiçoamento em Bioética Aplicada às Pesquisas em Seres Hu-manos (2013), Aperfeiçoamento em Educação para Jovens e Adultos pelo CEETEPS (2014) e Especialização em Gestão da Organização da Saúde Pública (UNIRIO/2014). Professora Universitária do Ensino Superior, da Faculdade de Tecnologia Dr. Thomaz Novelino em Franca - FATEC FRANCA, na Faculdade de Direito de Franca (2017) ministrando a Disciplina Direito Empresarial I. Contato: mrjunque@gmail.com. http://lattes.cnpq.br/0941478761964509.

${ }^{2}$ Bacharel em Direito pela Faculdade de Direito de Franca (2008); Graduado em Letras, com habilitação em Literatura, pela Universidade de Franca (2009); Pós-graduado em Estudos Linguísticos: texto e discurso, pela Universidade de Franca (2009); Pós-graduado em Direito Processual Civil Empresarial, pela Faculdade de Direito de Franca (2018); Pós-graduado em Psicologia Jurídica, pela Faculdade Única (2018); Pós-graduado em Direitos Humanos, pela Faculdade de Educação São Luís (2019); Pósgraduado em Língua Portuguesa: redação e oratória, pela Faculdade de Educação São Luís (2019); Pósgraduando em Direito Trabalhista e Previdenciário, pela Faculdade de Direito de Franca; Pós-graduando em Direito Penal e Processual Penal, pelo Instituto Elpídio Donizetti; Pós-graduando em Análise de Discurso Jurídico e Político, pela Faculdade Unyleya; Mestrando em Direito, pela Universidade de Araraquara. Professor da Faculdade de Direito de Franca (aprovado em $1^{\circ}$ lugar no concurso de substituto para a cadeira de Direito Penal I, II e III). Contato: tristao.adv@outlook.com. http://lattes.cnpq.br/3466054693450805.
} 


\title{
RESUMO
}

Esta pesquisa tem como escopo abordar as discussões que envolve-ram e ainda envolvem a questão do prazo e do tempo razoáveis na busca da solução de mérito à luz do Código de Processo Civil de 2015, sobretudo no que diz respeito aos textos dos artigos $4 .^{\circ}$ e $6 .^{\circ}$, da Lei n. $13.105 / 15$, vistos sob o prisma da sistemática processual. Como grande parte do Direito, tais controvérsias estão longe de se pacificarem, encontrando tanto aqueles que defendem tratar-se de um sistema positivo, quanto aqueles que o entendem negativo, ou, quiçá, até mesmo pior do que o sistema que previa o Código de Pro-cesso Civil de 1973. Trata-se, pois, de uma pesquisa exclusivamente bibliográfica e que se justifica não somente no âmbito acadêmico, mas também social, visto que, intrinsicamente relacionados (prazo e tempo) à obtenção de um direito, não seria justo que a legislação retroagisse (ou não), muito menos sem questionamentos.

Palavras-chave: Prazo Razoável. Tempo Razoável. Solução Integral de Mérito. Códi-go de Processo Civil de 2015.

\begin{abstract}
This research scopes the discussions that involved and still involve the reasonable term and time issue in the search for merit solution in the light of the 2015 Civil Process Code, especially regarding the texts from the 4th and 6th Articles of Law 13.105/15, seen from the per-spective of the procedural system. As great part of Law, such contro-versies are far from pacification, relating either to those who find it a positive system or to those who find it a negative one, or even worse than the system, that provides for the 1973 Civil Process Code. It is therefore about an exclusively bibliographic research that is also based not only on the academic field, but also on a social one due to the fact that, intrinsically relating (term and time) to the obtaining of a right, it would not be fair that the legislation retroacted (or not), espe-cially without questioning.
\end{abstract}

Keywords: Reasonable Term. Reasonable Time. Integral Merit Solution. 2015 Civil Process Code.

\section{INTRODUÇÃO}

O Código de Processo Civil de 2015 trouxe inúmeras mudanças na sistemática processual brasileira, forçando os operadores do Direito a se adaptarem e que juristas e doutrinadores repensassem seus posicionamentos. Nesse contexto, surgiram, como é próprio do Direito e de seus pensadores, diversas discussões a respeito do novo sistema, sendo parte delas relacionadas ao prazo e ao tempo razoáveis na busca de solução de mérito.

A expressão prazo e tempo razoáveis na solução de mérito ganhou enorme repercussão, primeiro porque alcançou o status de princípio; segundo por, na verdade, terem inter-relações e estarem expressos nos artigos $4 .^{\circ}$ e $6 .^{\circ}$, do Código de Processo Civil de 2015.

Porquanto o tema não tem interesse meramente procedimental, isto é, de preocupação pura e simples com o operador do Direito no caminhar do processo, mas sim porque há enorme reflexo na sociedade, sobretudo da parte que espera ver satisfeito o seu direito pleiteado. Ou, porque não lembrar, da parte contrária que espera ver o direito pleiteado da outra, 
negado e, assim, obter segurança jurídica no tocante ao objeto litigioso. Justifica-se, assim, a pesquisa tanto no campo acadêmico, quanto na esfera social.

Sabe-se, nesse sentido, que há tempos um litígio judicial é demasiadamente moroso, seja por causa de seu procedimento, nesse ponto abrangidos os recursos que lhes são inerentes, seja porque a máquina estatal não se encontra devidamente equipada, seja até porque não há mecanismos de controle e gestão processual.

O presente trabalho, visto que envolve a questão do tempo e do prazo no processo, principalmente relacionados na busca da solução de mérito, pautar-se-á na parte procedimental, por questões de delimitação, não deixando, todavia, de abordar outros pontos, mesmo que de maneira menos aprofundada.

A análise dos artigos $4 .^{\circ}$ e $6 .^{\circ}$, do Código de Processo Civil de 2015, é a base do trabalho, posto que os demais dispositivos serão analisados à luz de ambos, constituindo o objeto da pesquisa.

A metodologia é exclusivamente bibliográfica, tendo em vista que a Lei n. 13.105/15 é recente e não há como avaliar com a precisão que se espera de um trabalho científico os reais efeitos da mudança do Código de Processo Civil de 2015 e da efetiva aplicação dos artigos supramencionados. Muitos pontos estão longe de se pacificarem, principalmente nos Tribunais Superiores, existindo, portanto, ainda insegurança para o operador do Direito.

Por sua vez, o trabalho apresenta-se tendo às abordagens: Inicialmente comentários iniciais dos artigos $4 .^{\circ}$ e $6 .^{\circ}$, do Código de Processo Civil de 2015; seguindo, base da discussão acerca dos prazos e tempos razoáveis na busca da solução de mérito; a visão dos doutrinadores a respeito dos artigos 219, caput, 1.003, $\S 5^{\circ}$ e 200 , caput, todos do Código de Processo Civil de 2015; os artigos $4 .^{\circ}$ e $6 .^{\circ}$, do Código de Processo Civil de 2015, à luz da sistemática processual atual; os primeiros passos da Lei n. 13.105/15 na busca da solução de conflitos com resolução de mérito e, por derradeito, a apresentação do princípio da cooperação processual.

\section{COMENTÁRIOS INICIAIS DOS ARTIGOS 4.ำ E 6.ำ, DO CÓDIGO DE PROCESSO CIVIL DE 2015}


Inicialmente, é importante destacar que tanto o artigo $4 .^{\circ}$, quanto o artigo 6. ${ }^{\circ}$, do Código de Processo Civil de 2015, não possuem correspondentes no Código de Processo Civil de 1973.

Em razão disso e com inspiração, obviamente, na Constituição Federal, mais precisamente em seu inciso LXXVIII, do artigo $5 .^{\circ}$, que dispõe "a todos, no âmbito judicial e administrativo, são assegurados a razoável duração do processo e os meios que garantam a celeridade de sua tramitação", o legislador introduziu os dois artigos de forma a se harmonizar com a Carta Magna e orientar o operador do Direito.

Inclusive, há que se referenciar que o inciso LXXVIII, foi inserido no art. $5^{\circ}$, da Constituição Federal, a partir da EC n ${ }^{\circ} 45$, após ser firmado o Pacto de Estado em Favor de um Judiciário mais Rápido e Republicano $^{3}$, apelidado de Reforma do Judiciário. Pacto este acordado enter os chefes dos três poderes, consubstanciado nos compromissos fundamentais: implementação da reforma constitucional do judiciário, reforma do sistema recursal e dos procedimentos, defensoria pública e acesso à Justiça, juizados especiais e Justiças itinerantes, execução fiscal, precatórios, graves violações contra os direitos humanos, informatização, produção de dados e indicadores estatísticos, coerência entre a atuação administrativa e as orientações jurisprudenciais já pacificadas e incentivo à aplicação das alternativas.

Trata-se de verdadeira orientação, posto que os artigos $4 .^{\circ}$ e $6 .^{\circ}$, da Lei Adjetiva, possuem o status, dentro da normatividade, de verdadeiros princípios e não de regras.

O artigo $4 .^{\circ}$, da Lei Processual, denominado de princípio da duração razoável do processo, possui a seguinte redação: "As partes têm o direito de obter em prazo razoável a solução integral do mérito, incluída a atividade satisfativa".

Com relação às partes terem o direito de obter em prazo "razoável" a solução integral do mérito, incluída a atividade satisfativa, preleciona Humberto Dalla Bernardina de Pinho que:

Razoável será o tempo necessário para a cognição da causa até a efetiva entrega (ou não) do bem pretendido pela parte, ou seja, de todo o iter processual até a efetivação do provimento final. A razoável duração do processo tem como características:

\footnotetext{
${ }^{3}$ Pacto Republicano em Favor de um Judiciário mais Rápido e Republicano, apelidado de Reforma do Judiciário. Disponível em: <http://www.stf.jus.br/portal/cms/verNoticiaDetalhe.asp?idConteudo=63995>. Acesso em 1 jun. 2018.
} 


\begin{abstract}
A universalidade;
A limitabilidade;

A cumulatividade; $\mathrm{e}$

A irrenunciabilidade.

Seu conteúdo deve ser harmonizado com o conceito de jurisdição, no intento da efetividade, ao concentrarem-se, seja na busca de formas diferenciadas de tutuela de direitos, seja por meios alternativos de solução de conflitos, seja pela participação democrática do cidadão na persecução da solução do conflito submetido ao Judiciário, como formas de viabilizar o Estado Democrático de Direito e os novos conflitos da sociedade moderna. ${ }^{4}$
\end{abstract}

Por outro lado, o artigo 6. ${ }^{\circ}$, do Código de Processo Civil de 2015, denominado de princípio da cooperação processual, determina que: "Todos os sujeitos do processo devem cooperar entre si para que se obtenha, em tempo razoável, decisão de mérito justa e efetiva".

À primeira vista, seria possível imaginar uma grande evolução dentro do sistema processual civil. Ora, diversas são as adjetivações que legislador utiliza: razoável, integral, justa, efetiva, vocábulos animadores para qualquer operador do Direito ou qualquer jurisdicionado.

Expressões como "solução integral do mérito" e "cooperar entre si" são igualmente chamativas e tentadoras.

A verdade, porém, é que tanto as adjetivações, quanto as expressões acima mencionadas não são desprovidas de conteúdo jurídico e, por isso mesmo, não podem ser desprezadas ou relegadas, seja na interpretação dos próprios artigos, seja como vetores na exegese do sistema processual civil.

Com relação ao princípio da cooperação, preleciona Paulo Cesar Pinheiro Carneiro que este:

(...) não se limita aos participantes tradicionais do processo: autor e réu. Deve o juiz, sempre que necessário, especialmente nos processos cujo resultado possa alcançar um grande número de pessoas, permitir a intervenção de pessoas, órgãos ou de entidades com interesse, ainda que indireto na controvérsia. Assim, promover a realização de audiências públicas (art. 927, $\S 2^{\circ}$; art.983, $\S 1^{\circ}$; art. 1.038, II, v.g.) e até mesmo permitir o ingresso de outros personagens que possam colaborar para a realização da justiça, caso do amicus curiae (arts. 138 e 1.038, I), são corolários lógicos de uma das formas de cooperação do juiz com o deslinde da causa. Quanto maior for a

\footnotetext{
${ }^{4}$ PINHO, Humberto Dalla Bernardina de. Direito Processual Civil Contemporâneo: teoria geral do processo. 7. Ed. São Paulo: Saraiva, 2017, pp. 116-117.
} 
participação e, portanto, os elementos de informação, maior será a legitimidade democrática da decisão".(Wambier, 2015, p.71)

Importante salientar que da maneira como mencionado pelo autor o juiz também coopera, mas não como uma opção, mas sim como um dever inerente à responsabilidade do Poder ao qual se acha investido, que é o poder jurisdicional, de dizer o direito quando é suscitado a fazer. Nesse sentido ainda, cabe ressaltar que esse poder dever de cooperação do juiz, inserido através das modificações do Código de Processo Civil, atende ainda ao disposto no art. 93, IX, da Constituição Federal, que determina que todas as decisões do Poder Judiciário deverão ser fundamentadas, sob pena de nulidade.

Em sendo assim, deverá haver uma coerência, uma concatenação de ideias, lastreada por um raciocínio jurídico interno que leve a observância do sistema de direitos estabelecido e assim, acabando por também ser justificado através de um dever que se apresenta como externo, no sentido de que a decisão vai estar eivada de legitimação pelos procedimentos legalmente existentes.

Essa cooperação deve ser lastreada de diálogo entre as partes, devendo o juiz promover uma situação favorável, que dê condições e abertura às partes para quererem negociar e, portanto, cooperarem num objetivo comum que é a resolução do conflito ou da demanda.

Nesse sentido explica François Ost ao apresentar três modelos de juízes, quais sejam Júpiter, Hércules e Hermes ${ }^{6}$, preleciona que o juiz tem o dever de interagir entre as partes no objetivo de uma solução justa para a lide.

Dessa maneira, como se constata, razoável não pode confundirse com rapidez da mesma forma que cooperação não se confunde necessariamente com a desistência ou a renúncia de um direito positivado, muito embora isso ocorra na autocomposição, uma das várias formas de composição da lide.

Por uma questão de obviedade e lógica, pode-se afirmar que se há cooperação, o processo não se estenderá por um prazo que não seja ra-

\footnotetext{
${ }^{5}$ WAMBIER, Luiz Rodrigues et al. Primeiros comentários ao novo CPC: artigo por artigo. São Paulo: Revista dos Tribunais, 2015, p. 71.

${ }^{6}$ OST, François. Júpiter, Hércules e Hermes: três modelos de Juez. Tradução de Isabel Lifante Vidal. In: DOXA - n.14, 1993, pp. 169-194. Disponível em: <http://www.cervantesvirtual.com/...jpiter-hrcules-y-hermes--tres-modelos-de-juez>. Acesso em 1 jun. 2018.
} 
zoável, por essa razão a promoção e a manutenção do diálogo entre as partes com vistas ao alcance de um consenso é o caminho mais eficaz para que os dois princípios sejam vivenciados e haja eficiência.

Ost ao propor os três modelos de juízes, aponta que Hermes representa o Direito Pós-moderno, sendo que

Es a Hermes, dios de la comunicación y de la circulación, dios de la intermediación, personaje modesto en el oficio de representante y portavoz que es olvidado en beneficio dela prosecución del juego mismo, a quien confiamos la tarea de simbolizar esta teoría lúdica del Derecho. ${ }^{7}$

Por essa razão, no direito representado por Hermes se configura como um direito que demanda interpretação, tendo como mediador o juiz dos problemas e lacunas presentes nas relações sociais conflituosas, dessa maneira permitindo haja a integração social através do consenso, resolvendo e pondo fim à relação processual, com a ajuda dos interessados.

Dessa maneira bem explica Ost:

Signo lingüístico, el Derecho pide en efecto ser interpretado por sus destinatarios; manifestación de voluntad, el Derecho pide ser interiorizado y aceptado. A partir del momento en que los «sujetos de Derecho» -que no son sujetos del Derecho, sino mejor sujetos de Derecho, es decir, todo a la vez, seres susceptibles de derechos y coautores del Derecho- reconstruyen mentalmente el mensaje que se les dirige y mediatizan su puesta en práctica con una operación de voluntad (que es también una manifestación de libertad), el Derecho se configura como algo necesariamente inacabado, siempre en suspenso y siempre relanzado, indefinidamente retomado en la mediación del cambio. ${ }^{8}$

Além disso, se deve verificar que o legislador, logo no início do Código de Processo Civil de 2015, deixou clara a preferência para a solução integral do mérito em detrimento da sua não resolução. É o que a doutrina chama de primazia do julgamento de mérito.

Sendo assim e como em qualquer texto - texto aqui entendido como um enunciado dotado de sentido -, é imperioso analisar os artigos

\footnotetext{
${ }^{7}$ Ibidem. p. 182.

${ }^{8}$ OST, François. Júpiter, Hércules e Hermes: três modelos de Juez. Tradução de Isabel Lifante Vidal. In: DOXA - n.14, 1993, pp. 169-194. Disponível em: <http://www.cervantesvirtual.com/...jpiter-hrcules-y-hermes--tres-modelos-de-juez>. Acesso em 1 jun. 2018. p. 183.
} 
estudados, linguisticamente, sem a supressão ou a adoção de sentido diverso a vocábulos (respeitando aqueles possíveis dentro do sistema hermenêutico), alinhando a interpretação dentro do sistema processual civil.

\subsection{BASE DA DISCUSSÃO ACERCA DOS PRAZOS E TEMPOS RAZOÁVEIS NA BUSCA DA SOLUÇÃO DE MÉRITO}

Logo que o Código de Processo Civil de 2015 entrou em vigor ou até mesmo no período de sua vacância, inúmeras discussões ganharam espaço entre os operadores do Direito, muitas das quais pautadas no senso comum, sem qualquer base científica.

Não diferente ocorreu em relação ao tempo e ao prazo do processo, que recebeu severas críticas, visto que, conquanto os artigos $4 .^{\circ} \mathrm{e}$ $6^{\circ}$, da Lei Adjetiva, empregassem o termo "razoável", considerável parcela dos profissionais passou a defender que houve um retrocesso no tocante ao Código de Processo Civil de 1973.

Três, dentro outros, foram os pontos principais utilizados para defender referida tese: a) a contagem do prazo processual em dias úteis (artigo 219, caput, do Código de Processo Civil de 2015); b) a padronização do prazo recursal em 15 (quinze) dias - aumentando, por exemplo, o prazo para interposição de agravo de instrumento -, exceto os embargos de declaração (artigo 1.003, § 5. ${ }^{\circ}$, do Código de Processo Civil de 2015); c) a suspensão do prazo processual nos dias compreendidos entre 20 de dezembro e 20 de janeiro, inclusive (artigo 220, caput, do Código de Processo Civil de 2015).

Referidos pontos foram os mais discutidos, o que não quer dizer que outros não influenciaram os debates. Assim, o prazo para a impugnação da assistência judiciária gratuita passou de 05 (cinco) dias (artigo 51, caput, do Código de Processo Civil de 1973) para 15 (quinze) dias (artigo 120, caput, do Código de Processo Civil de 2015); o prazo para a emenda da inicial passou de 10 (dez) dias (artigo 284, caput, do Código de Processo Civil de 1973) para 15 (quinze) dias (artigo 321, caput, do Código de Processo Civil de 2015), entre outros.

Portanto, de acordo com parte dos pensadores, o que era, então, para ser célere ou, no mínimo, razoável, teria passado a ser ainda mais mo- 
roso, primeiro porque, agora, computados em dias úteis (os prazos), segundo com o aumento dos prazos entre os Códigos de Processo Civil de 1973 e de 2015, por último, porquanto fixado o tempo de suspensão dos prazos no final e no início dos anos.

\subsubsection{A VISÃO DOS DOUTRINADORES A RESPEITO DOS ARTIGOS 219, CAPUT, 1.003, § 5. E 220, CAPUT, TODOS DO CÓDIGO DE PROCESSO CIVIL DE 2015}

Conforme mencionado no item anterior, as primeiras críticas sobre o tempo e o prazo no processo civil recaíram, sobretudo, na contagem do prazo processual em dias úteis, na padronização dos prazos recursais e na suspensão do prazo processual entre os dias 20 de dezembro e 20 de janeiro, inclusive.

A respeito do artigo 219, caput, do Código de Processo Civil de 2015, grande parte da doutrina limitou-se a reproduzir o texto da lei e, quando muito, explicou que a regra contida no dispositivo aplica-se somente a dias - não se aplica a minutos, meses e anos -, não se aplicando, também, aos prazos de direito material, a exemplo da prescrição e da decadência. Discutiram, também brevemente, a aplicação da contagem dos prazos em dias úteis nos Juizados Especiais Cíveis. Nesse sentido, Nelson Nery Junior e Rosa Maria de Andrade Nery; Luiz Guilherme Marinoni, Sérgio Cruz Arenhart e Daniel Mitidiero; Rodrigo da Cunha Lima Freira e Maurício Ferreira Cunha; bem como Leio Luiz Streck, Clarissa Tassinari, Rafael Fonseca Ferreira e Ziel Ferreira Lopes.

De modo diverso, Daniel Amorim Assumpção Neves, com toda a maestria que lhe é inerente, além de também fazer as colocações acima apontadas, enfrenta a questão e discorre da seguinte maneira sobre o assunto:

Sendo advogado militante no contencioso cível, não tenho como deixar de saudar efusivamente a novidade legislativa. Nem é preciso muita experiência forense para compreender que, com prazos em trâmite durante o final de semana, o advogado simplesmente não tem descanso. Basta imaginar o termo inicial de contestação 
numa ação cautelar numa quarta-feira com feriado na quinta e na sexta. $^{9}$

Perfeita a colocação do professor e advogado, exceto na parte em que menciona ação cautelar, modalidade extinta pelo Código de Processo Civil de 2015. E, assim, continua o doutrinador:

Com o pedido de desculpas antecipadas aos que entendem o contrário, a crítica de que a previsão legal ofende o princípio da celeridade processual destoa em absoluto da realidade forense. O processo demora demais, muito além do tempo razoável previsto no art. 5. ${ }^{\circ}, \mathrm{LXXVIII}$, da CF, mas culpar os prazos por isso é inocência. A culpa na realidade é do tempo morto, ou seja, o tempo de espera entre os atos processuais, principal culpado pela morosidade procedimental. Com audiências sendo designadas para meses depois, com autos conclusos a perder de vista, com esperas dramáticas pela mera juntada de uma peça, entender que a contagem de prazos somente durante os dias úteis irá atrasar o andamento do processo é trabalhar em paralelo com a realidade. ${ }^{10}$

O pensamento de Daniel Amorim Assumpção Neves harmonizase perfeitamente com o que foi citado na introdução, isto é, de que o processo é moroso, seja porque a máquina estatal não se encontra devidamente equipada, seja porque não há mecanismos de controle e gestão processual. Poder-se-ia acrescentar a (boa ou má) vontade de trabalhar do servidor público, mas referida afirmativa seria meramente empírica e sem embasamento científico, motivo pelo qual é melhor deixá-la de lado.

Nesse sentido, afirmar que o processo, após o advento do Código de Processo Civil de 2015, tornou-se mais moroso pela contagem do prazo em dias úteis é desconhecer o ambiente forense e a forma como tramitam os procedimentos.

Esse pensamento é fácil de ser constatado quando se observa o procedimento de duas demandas quase idênticas (não poderiam ser idênticas por causa da litispendência), em que, na mesma comarca, tramitam em varas diferentes. Sendo o prazo o mesmo, dificilmente as duas seriam julgadas ao mesmo tempo ou em tempo próximo.

O primeiro argumento resta, dessa forma, facilmente rebatido.

Por outro lado, o artigo 1.003, § 5. ${ }^{\circ}$, do Código de Processo Civil de 2015, também em nada cria óbice para o bom andamento do processo -

\footnotetext{
${ }^{9}$ NEVES, Daniel Amorim Assumpção. Novo Código de Processo Civil Comentado. 2. ed. rev. E atual. Salvador: Ed. Juspodivm, 2017. p. 370.
}

${ }^{10}$ Ibidem. 
e muito menos gera retrocesso se comparado com o Código de Processo Civil de 1973 -, possuindo este texto: "Excetuados os embargos de declaração, o prazo para interpor os recursos e para responder-lhes é de 15 (quinze) dias".

Nos termos do artigo 508, do Código de Processo Civil de 1973, constava a seguinte redação: "Na apelação, nos embargos infringentes, no recurso ordinário, no recurso especial, no recurso extraordinário e nos embargos de divergência, o prazo para interpor e para responder é de quinze dias".

Somado a isso, ainda no código anterior, o artigo 536 dispunha: "Os embargos serão opostos, no prazo de 5 (cinco) dias, em petição dirigida ao juiz ou relator, com indicação do ponto obscuro, contraditório ou omisso, não estando sujeitos a preparo".

Ademais, os embargos de divergência, tanto no Código de Processo Civil de 1973 (artigo 546, parágrafo único), quanto no Código de Processo Civil de 2015 (artigo 1.044, caput), têm o prazo estabelecido pelo regimento interno do tribunal superior.

Nesse sentido, Jorge Amaury Nunes explica que:

Pela regência da matéria do Código de 2015, o prazo para interposição de recursos cíveis foi quase que totalmente unificado. Com efeito, ressalvados os embargos de declaração, que hão de ser opostos no prazo de cinco dias (art. 1.020), os demais recursos serão interpostos e respondidos no prazo de quinze dias. ${ }^{11}$

No mesmo sentido, Daniel Amorim Assumpção Neves ensina que:

O Novo Código de Processo Civil torna o prazo recursal mais homogêneo, prevendo em seu art. $1.003, \S 5 .^{\circ}$, que todos os recursos passam a ter prazo de 15 dias (úteis), salvo os embargos de declaração, que mantêm o prazo atual de 5 dias. ${ }^{12}$

Ora, ao comparar os dois códigos, observa-se que o único recurso que, de fato, teve seu prazo alterado em dias, foi o agravo de instrumento, o qual era de 10 (dez) - artigo 522, caput, do Código de Processo Civil de

\footnotetext{
${ }^{11}$ NUNES, Jorge Aumaury. In: STRECK, Lenio Luiz. O que é isto - decido conforme minha consciên-cia? 3.Ed. Porto Alegre: Livraria do Advogado, 2012. p. 1361.

${ }^{12}$ NEVES, Daniel Amorim Assumpção. Novo Código de Processo Civil Comentado. 2. ed. rev. E atual. Salvador: Ed. Juspodivm, 2017. pp. 1827-1828.
} 


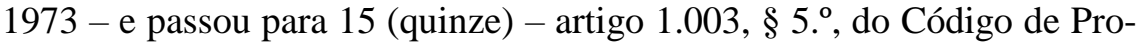
cesso Civil de 2015.

Os demais recursos ou mantiveram seus prazos ou foram extintos, a exemplo do agravo retido e dos embargos infringentes, o que representou um grande avanço no sistema processo civil.

Sendo assim, culpar o simples aumento de 05 (cinco) dias em um único recurso e criticar a quase total unificação dos prazos é incoerência pura.

O último ponto que teve bastante repercussão com a entrada em vigor do Código de Processo Civil de 2015 no tocante ao tempo e ao prazo processuais está compreendido no artigo 220, caput, de citado Diploma. Referido artigo dispõe que: "Suspende-se o curso do prazo processual nos dias compreendidos entre 20 de dezembro e 20 de janeiro, inclusive".

Mencionado dispositivo possuía quase semelhante correspondente no Código de Processo Civil de 1973, mais precisamente no artigo 179, que era dotado de seguinte texto: "A superveniência de férias suspenderá o curso do prazo; o que lhe sobejar recomeçará a correr do primeiro dia útil seguinte ao termo das férias".

Comparando os dois dispositivos, é possível observar que houve apenas a delimitação de quando o prazo se suspende, haja vista que sempre houve suspensão dos prazos no final do ano e no começo do ano seguinte, exceto para casos excepcionais.

Aliás, porque "ressalvadas as férias individuais e os feriados instituídos por lei, os juízes, os membros do Ministério Público, da Defensoria Pública e da Advocacia Pública e os auxiliares da Justiça exercerão suas atribuições durante o período previsto no caput", nos termos do artigo 220, $\S 11^{\circ}$, do Código de Processo Civil de 2015, as próprias instituições, por meio de normas internas, estabelecem formas de rodízio de servidores em parte do período compreendido entre 20 de dezembro e 20 de janeiro.

Segundo Luiz Guilherme Marinoni, Sérgio Cruz Arenhart e Daniel Mitidiero:

$\mathrm{O}$ advento do recesso forense determina a suspensão dos prazos processuais. Nos juízos em que não há férias forenses (arts. 93, XII, $\mathrm{CF}$ ), ressalvadas as férias individuais e os feriados legais, o Poder Judiciário, o Ministério Público, a Defensoria Pública, a Advocacia Pública e os auxiliares da Justiça exercerão suas atribuições durante o recesso. É vedada, porém, a realização de audiências e de sessões de julgamento durante o recesso. Terminado o recesso, os prazos 
voltam a correr por tempo igual ao que faltava para sua complementação. ${ }^{13}$

Sendo assim, não houve retrocesso em relação ao Código de Processo Civil de 1973. Houve, na verdade, verdadeira segurança jurídica ao se saber, exatamente, qual o período de suspensão dos prazos processuais, não ficando mais os advogados reféns de normas estabelecidas pelos tribunais.

Não houve, igualmente, qualquer prejuízo para o jurisdicionado, haja vista as exceções legais, a exemplo do artigo 214, incisos I e II, do Código de Processo Civil de 2015, bem como por aquilo que foi explanado no item 1.1.1 desta pesquisa, nas palavras de Daniel Amorim Assumpção Neves.

Ademais, deve-se bem ressaltar, ainda nas palavras do eminente doutrinador, que não há paralização da Justiça. Consoante suas palavras:

\footnotetext{
Significa dizer que atos judiciais que não dependem da participação das partes, como ocorre com a prolação de despachos, decisões interlocutórias, sentenças e decisões monocráticas proferidas por relator em tribunal, podem ser normalmente praticados durante o período do recesso forense. $\mathrm{E}$ as partes poderão ser intimadas desses atos durante o feriado forense, tendo início a contagem de seu prazo no primeiro dia útil subsequente ao do fim do feriado, ou seja, dia 20 de janeiro. ${ }^{14}$
}

Portanto, os três pontos acima enfrentados, além de não configurarem retrocesso em relação ao Código de Processo Civil de 1973, também não configuram qualquer afronta aos princípios instituídos nos artigos $4 .^{\circ}$ e 6. ${ }^{\circ}$, do Código de Processo Civil de 2015.

De se pensar, aliás, que os descansos dados aos advogados por meio da nova legislação, seja nos dias não úteis, seja nos recessos, seja aumentando ainda que em um único recurso o seu prazo, possibilitam-lhes melhor lapidar suas peças e, consequentemente, melhor atender os interesses das partes que patrocinam.

\footnotetext{
${ }^{13}$ MARINONI, Luiz Guilherme et al. Novo código de Processo Civil Comentado. 3. ed. São Paulo: Editora Revista dos Tribunais, 2017. p. 335.

${ }^{14}$ NEVES, Daniel Amorim Assumpção. Novo Código de Processo Civil Comentado. 2. ed. rev. E atual. Salvador: Ed. Juspodivm, 2017. p. 372-373.
} 


\section{OS ARTIGOS 4. E 6., DO CÓDIGO DE PROCESSO CIVIL DE 2015, À LUZ DA SISTEMÁTICA PROCESSUAL ATUAL}

No item 2 da presente pesquisa, foi afirmado que como em qualquer texto - texto aqui entendido como um enunciado dotado de sentido , é imperioso analisar os artigos estudados $\left(4 .^{\circ}\right.$ e $6 .^{\circ}$, do Código de Processo Civil de 2015), linguisticamente, sem a supressão ou a adoção de sentido diverso a vocábulos (respeitando aqueles possíveis dentro do sistema hermenêutico), alinhando a interpretação dentro do sistema processual civil.

Os operadores do Direito e mesmo os doutrinadores, na ânsia de debater a matéria ou escrever a respeito, extraíram de citados artigos as expressões "prazo razoável" e "tempo razoável", como se isoladas pudessem ser aplicadas, independentemente do sistema processual civil instrumental ao qual se acham inseridos, tornando-os vazios de sentido se assim forem concebidos.

Ora, nenhuma forma de interpretação permite que isso seja feito, sob o grave risco de se incorrer em erro hermenêutico ou exegético.

Dessa forma, no artigo 4. ${ }^{\circ}$, da Lei Processual, é importante destacar que intrinsicamente à expressão obtenção de um direito em "prazo razoável", está objetivada a solução integral de mérito, incluindo a atividade satisfativa.

Na mesma esteira, no artigo $6 .^{\circ}$, da Lei Adjetiva, ao lado do "tempo razoável", está, antes, a cooperação de todos os sujeitos do processo e, depois, a decisão de mérito justa e efetiva.

Assim, enquanto o primeiro artigo foi denominado de princípio da duração razoável do processo, o segundo foi batizado de princípio da cooperação processual.

Impossível, nesse sentido, não observar que o legislador frisou, por duas vezes, a importância da solução/decisão de mérito, incluindo a atividade satisfativa, adjetivada de justa e efetiva, em prejuízo da não resolução.

No entanto, a atividade satisfativa somente poderá ocorrer mediante a interpretação que observa o círculo hermenêutico ${ }^{15}$ proposto pela

\footnotetext{
${ }^{15}$ STRECK, Lenio Luiz. O que é isto - decido conforme minha consciência? 3.Ed. Porto Alegre: Livraria do Advogado, 2012, p. 75. O autor explica o que vem a ser o círculo hermenêutico: “...interpretar é compreender. E compreender é aplicar. A hermenêutica não é mais metodológica. Não mais interpretamos para compreender, mas, sim, compreendemos para interpretar. A hermenêutica não é
} 
hermenêutica filosófica que não pode ser vista nos termos da hermenêutica clássica, baseada em critérios metafísicos.

Para tanto, o legislador criou formas para que se atinja a solução de mérito nos termos mencionados no parágrafo anterior.

\subsection{PRIMEIROS PASSOS DA LEI N. 13.105/15 NA BUSCA DA SOLUÇÃO DE CONFLITOS COM RESOLUÇÃO DE MÉRITO}

Ao mesmo tempo em que o Código de Processo Civil de 2015 contempla o princípio de direito de ação e da inafastabilidade da jurisdição, em seu artigo 3..$^{\circ}$ caput, prevê, em seus três parágrafos, que: a) será permitida a arbitragem, na forma da lei; b) a promoção da solução consensual de conflitos, sempre que possível, pelo Estado; c) a conciliação, a mediação e outros métodos de solução consensual de conflitos, os quais deverão ser estimulados pelos sujeitos processuais, inclusive no curso do processo judicial.

Extrai-se, portanto, do artigo $3 .^{\circ}$ - conquanto deixe evidente o direito de ação, que, se preenchida suas condições, deverá ter um trâmite regular, com a devida instauração do processo, caso também estejam presentes seus pressupostos, tendo, por fim, um julgamento motivado por juiz competente e imparcial - o estímulo a outros métodos de solução de conflitos. É o que a doutrina vem chamando de modelo multiportas de justiça (multi-door dispute resolution). ${ }^{16}$

O primeiro abordado pelo próprio artigo, em seu $\S 1 .^{\circ}$, trata da arbitragem, instituto de suma importância, pois, ao trocar a jurisdição estatal pela jurisdição particular, diminui o excesso de demandas.

Além de diminuir o excesso de demandas no Poder Judiciário, permitindo que as outras tenham seu curso mais rápido, o trâmite da arbitragem é mais célere, inclusive não estando sujeita a sentença arbitral, caso não haja qualquer vício, a recurso, nos termos do artigo 18, da Lei n. 9.307/96.

mais reprodutiva (Ausleung); é, agora, produtiva (Sinngebung). A relação sujeito-objeto dá lugar ao círculo-hermenêutico.

${ }^{16}$ DIDIER JR., Fredie; ZANETI JR., Hermes. Justiça multiportas e tutela constitucional adequada: autocomposição em direitos coletivos. Civil Procedure Review, v.7, n.3: 59-99, sept.-dec., 2016 ISSN 2191-1339. 
Sobre a arbitragem, Rinaldo Mouzalas, João Otávio Neto e Eduardo Madruga, explicam quem:

\begin{abstract}
Na arbitragem, regulada pela Lei $n^{\circ} 9.307 / 1996$, a solução do conflito se dá, tal qual na jurisdição estatal, pela intervenção de terceiro imparcial. Este, porém, é estranho ao Poder Judiciário. Trata-se de atividade jurisdicional exercida pelo particular, com permissão legal do Estado (art. $3^{\circ}, \S 1^{\circ}$, do CPC/2015). Prova disso é que a sentença arbitral faz coisa julgada, apenas podendo ser desconstituída, judicialmente, se presente algum dos vícios previstos no art. 32 da Lei de Arbitragem. ${ }^{17}$
\end{abstract}

\title{
E complementam os autores:
}

A instituição de arbitragem pelas partes é feita por meio da convenção de arbitragem, que compreende a cláusula compromissória e o compromisso arbitral. A cláusula compromissória é firmada previamente ao litígio. As partes, em um negócio jurídico, estabelecem que, em surgindo divergências relativas ao próprio negócio, elas serão resolvidas pela arbitragem. O compromisso arbitral, por sua vez, é firmado pelas partes após o surgimento da controvérsia. Trata-se de um negócio jurídico em que, em uma controvérsia específica, renuncia-se à atividade jurisdicional oferecida pelo Estado, substituindo-a pela arbitragem. O árbitro será pessoa capaz e de confiança das partes. ${ }^{18}$

Trata-se, pois, de um método de solução de conflitos que cada vez mais ganha espaço no âmbito forense, oportunizando aos litigantes ou futuros litigantes que tenham uma solução mais rápida e eficaz.

Importante, ainda, ressaltar, que a decisão final do árbitro constitui título executivo extrajudicial, nos termos do artigo 515, inciso VII, do Código de Processo Civil de 2015, sendo, portanto, o processo de conhecimento submetido à jurisdição privada, mas nunca o processo de execução, ante a ausência de poderes do árbitro para fazer cumprir a determinação.

O artigo 3. ${ }^{\circ}, \S 2 .^{\circ}$, da Lei Processual, dispõe que: "O Estado promoverá, sempre que possível, a solução consensual dos conflitos”, não explicando, todavia, qual e como será essa promoção.

Assim, utilizando-se das lições de Leonardo Carneiro da Cunha é possível compreender que:

\footnotetext{
${ }^{17}$ MOUZALAS, Rinaldo et al. Processo Civil. 9. ed. rev., ampl. e atual. Salvador: Ed. JusPodivm, 2017. pp. 86-87.

${ }^{18}$ MOUZALAS, Rinaldo et al. Processo Civil. 9. ed. rev., ampl. e atual. Salvador: Ed. JusPodivm, 2017. p. 86.
} 
$\mathrm{O} \S 2 .^{\circ}$ do art. $3 .^{\circ}$ constitui exemplo de legislação simbólica, enunciando uma declaração legal de instituição de uma política pública. O dispositivo ratifica a Resolução n. 125, de 2010, do CNJ, que dispõe sobre a política judiciária nacional de tratamento adequado dos conflitos de interesses no âmbito do Poder Judiciário. Nos termos da citada resolução, cabe aos órgãos judiciários oferecer mecanismos de solução de controvérsias, em especial os chamados meios consensuais, como a mediação e a conciliação, além de prestar atendimento e orientação ao cidadão. Na implementação dessa política judiciária nacional, serão observadas a centralização das estruturas judiciárias, a adequada formação e treinamento de servidores, conciliadores e mediadores, bem como o acompanhamento estatístico específico. $^{19}$

Depreende-se, nesse sentido, da lição do doutrinador, que, além de oferecer meios alternativos de solução de conflitos, a política judiciária nacional tem como objetivo, entre outros, o treinamento de servidores, conciliadores e mediadores, bem como o de prestar atendimento e orientação ao cidadão.

Referida política judiciária nacional tem se mostrado eficaz, principalmente com a criação dos CEJUSCs - Centros Judiciários de Solução de Conflitos e Cidadania -. No site do Conselho Nacional de Justiça é possível verificar o seguinte:

Os CEJUSCs devem, necessariamente, abranger três setores: setor pré-processual, setor processual e setor de cidadania (artigo $10 \mathrm{da}$ Resolução CNJ n. 125/2010 do Conselho Nacional de Justiça). Para funcionarem, os CEJUSCs devem contar, em sua estrutura, com um juiz coordenador e, eventualmente, com um adjunto, devidamente capacitados, aos quais cabe a administração dos três setores e a fiscalização do serviço de conciliadores e mediadores. Devem possuir, também, ao menos um servidor com dedicação exclusiva, capacitado em métodos consensuais de solução de conflitos, para triagem e encaminhamento adequado de casos (artigo $9^{\circ}$ da Resolução CNJ n. 125/2010 do CNJ) ${ }^{20}$.

Necessário reconhecer a importância da criação dos CEJUSCs conquanto não instalados em muitas comarcas -, não só no tocante à utilização de métodos consensuais de solução de conflitos, mas também no que diz respeito ao setor de cidadania, capaz de atender e orientar o cidadão.

${ }^{19}$ CUNHA, Leonardo Carneiro da. Art. $3^{\circ}$. In: STRECK, Lenio, Luiz; NUNES, Dierle; Comentários ao Código de Processo Civil. 2. ed. São Paulo: Saraiva, 2017. p. 33.

${ }^{20}$ BRASIL. Conselho Nacional de Justiça. Resolução $\mathbf{N}^{\mathbf{0}} 125$ de 29/11/2010. Disponível em: <http://www.cnj.jus.br/busca-atos-adm?documento=2579>. Acesso em 30 mai. 2018. 
É nesse contexto que ganham mais espaço a mediação e a conciliação, vocábulos muitas das vezes utilizados como sinônimos, mas que possuem especificidades próprias ${ }^{21}$. A confusão ocorre não só no senso comum, mas também na esfera doutrinária. Nesse sentido, Fábio Alexandre Coelho, ao tratar do caso, afirma, erroneamente, que: "Em sua atividade, o mediador deve salientar a importância da conciliação [g. n.], esclarecer os pontos controvertidos a respeito do litígio e intensificar a comunicação". ${ }^{22}$

$O$ certo é que a diferença ou as especificidades entre conciliação e mediação se dá na própria legislação processual civil. De acordo com o artigo 165, § 2. . do Código de Processo Civil de 2015:

O conciliador, que atuará preferencialmente nos casos em que não houver vínculo anterior entre as partes, poderá sugerir soluções para o litígio, sendo vedada a utilização de qualquer tipo de constrangimento ou intimidação para que as partes conciliem.

Se o $22^{\circ}$ norteia o operador do Direito a respeito da conciliação, o $\S 3 .^{\circ}$ o norteia no tocante à mediação:

O mediador, que atuará preferencialmente nos casos em que houver vínculo anterior entre as partes, auxiliará aos interessados a compreender as questões e os interesses em conflito, de modo que eles possam, pelo restabelecimento da comunicação, identificar, por si próprios, soluções consensuais que gerem benefícios mútuos.

Assim, enquanto o conciliador propõe soluções, objetivando o acordo em casos em que não há vínculo anterior ao litígio entre as partes; o mediador apenas cria um ambiente com o escopo de restabelecer a comunicação entre as partes, o que pressupõe um vínculo, antes do litígio, existente entre elas.

O certo é que, de uma forma ou de outra, o Código de Processo Civil de 2015 estimula a solução consensual do litígio. Nas palavras de Luiz Guilherme Marinoni, Sérgio Cruz Arenhart e Daniel Mitidiero:

\footnotetext{
${ }^{21}$ O Governo Federal através do Ministério da Justiça, com a preocupação de distinguir os institutos e torná-los popularizados, para um alcance de utilização cada vez maior, criou a ENAM - Escola Nacional de Conciliação e Mediação, ofertando cursos periódicos, abertos à população e interessados no assunto, para que se capacitem e possam aplicar a mediação e a conciliação de maneira a beneficiar cada vez mais a população. Disponível em: <http://www.justica.gov.br/seus-direitos/politicas-de-justica/backup-fev-2018/enam/enam>. Acesso realizado em 1 jun. 2018.

${ }^{22}$ COELHO, Fábio Alexandre. Teoria Geral do Processo. Bauru: Livraria e Editora Spessotto, 2016. p. 112.
} 
O novo Código tem como compromisso promover a solução consensual do litígio, sendo uma das suas marcas a viabilização de significativa abertura para a autonomia privada das partes - o que se manifesta não só no estimula a que o resultado do processo seja fruto de um consenso das partes (art. 3..$^{\circ}$ §§ 3..$^{\circ}$ e $3 .^{\circ}$, do CPC), mas também na possibilidade de estruturação contratual de determinados aspectos do processo (negócios processuais, art. 190, CPC, e calendário processual, art. 191, CPC). O juiz dirigirá o processo com a incumbência de promover, a qualquer tempo, a autocomposição, preferencialmente com auxílio de conciliadores e mediadores judiciais (art. 139, $\mathrm{V}, \mathrm{CPC}) .^{23}$

Ao se estimular e possibilitar a autocomposição, a qualquer tempo, resta mais evidente que a contagem do prazo processual em dias úteis (artigo 219, caput, do Código de Processo Civil de 2015); a padronização do prazo recursal em 15 (quinze) dias - aumentando, por exemplo, o prazo para interposição de agravo de instrumento -, exceto os embargos de declaração (artigo 1.003, § 5. ${ }^{\circ}$, do Código de Processo Civil de 2015); e a suspensão do prazo processual nos dias compreendidos entre 20 de dezembro e 20 de janeiro, inclusive (artigo 220, caput, do Código de Processo Civil de 2015), são questões que ficam, de fato, em segundo plano e em nada comprometem o bom andamento do processo em tempo e prazo razoáveis.

Isso porque, aquele que, verdadeiramente, quiser resolver o litígio, possui formas para tanto, da mesma maneira que aquele que desejar retardá-lo ainda encontrará brechas na legislação. Não é, pois, o prazo ou o tempo que resolverá a morosidade do processo.

\subsection{PRINCÍPIO DA COOPERAÇÃO PROCESSUAL}

Consoante mencionado no corpo deste trabalho, o artigo $6 .^{\circ}$, do Código de Processo Civil de 2015, dispõe que: "Todos os sujeitos do processo devem cooperar entre si para que se obtenha, em tempo razoável, decisão de mérito justa e efetiva".

Também já foi citado que o Estatuto Processual estimula a busca da decisão de mérito de forma justa e efetiva, sobretudo de maneira consensual, que deverá ser instigada não só por juízes, mas também por advogados, defensores públicos e membros do Ministério Público.

\footnotetext{
${ }^{23}$ MARINONI, Luiz Guilherme et al. Novo código de Processo Civil Comentado. 3. ed. São Paulo: Editora Revista dos Tribunais, 2017. p. 284.
} 
A questão agora em destaque trata-se do dever de cooperação processual. Sobre o tema, Daniel Amorim Assumpção Neves prevê uma visão salutar e outra, utópica. Segundo seus ensinamentos:

Seguir a tendência de legislações estrangeiras, em especial a alemã, na propositura de um sistema comparticipativo/cooperativo é benéfico ao processo porque, centrando-se em deveres do juiz, permite uma participação mais ativa das partes na condução do processo e aumenta as chances de influenciarem de maneira efetiva na formação do convencimento judicial. Trata-se, portanto, de incluir as partes como também responsáveis pelo desenvolvimento processual, que não deve ser tarefa exclusiva do juiz. Sob esse ponto de vista, é salutar falar em princípio cooperativo e o art. $6 .^{\circ}$ do Novo CPC deve ser saudado.

Por outro lado, interpretar o dispositivo legal como previsão que exige das partes uma cooperação entre si, outorgando-lhes um dever que contraria seus próprios interesses defendidos em juízo, é utopia e tornará o dispositivo morto. ${ }^{24}$

No mesmo sentido entendem Luiz Guilherme Marinoni, Sérgio Cruz Arenhart e Daniel Mitidiero, para que:

(...) E aqui importa desde logo deixar claro: a colaboração no processo não implica colaboração entre as partes - qualquer leitura do art. $6^{\circ}$, do CPC, nesse sentido é equivocada. As partes não querem colaborar. A colaboração no processo que é devida no Estado Constitucional é a colaboração do juiz para com as partes. Gize-se: não se trata de colaboração entre as partes. As partes não colaboram e não devem colaborar entre si simplesmente porque obedecem a diferentes interesses no que tange à sorte do litígio. O máximo que se pode esperar é uma colaboração das partes para com o juiz no processo civil. ${ }^{25}$

Em que pesem as justificativas dos doutrinadores, o assunto merece melhor reflexão. Primeiro, porque seus entendimentos - o segundo de Daniel Amorim Assumpção Neves - são notadamente contrários à letra da lei, que dispõe todos os sujeitos do processo devem cooperar entre si. Ora, em nenhum momento a legislação especifica que as partes devem cooperar apenas com o juiz e este com as partes.

\footnotetext{
${ }^{24}$ NEVES, Daniel Amorim Assumpção. Novo Código de Processo Civil Comentado. 2. ed. rev. e atual. Salvador: Ed. Juspodivm, 2017. p. 34.

${ }^{25}$ MARINONI, Luiz Guilherme et al. Novo código de Processo Civil Comentado. 3. ed. São Paulo: Editora Revista dos Tribunais, 2017. p. 162.
} 
De fato, as partes devem cooperar com o juiz da mesma forma que ele deve cooperar com as partes. Não há, todavia, qualquer impedimento para que as partes cooperem umas com as outras até porque "aquele que de qualquer forma participa do processo deve comportar-se de acordo com a boa-fé" (artigo 5. ${ }^{\circ}$, do Código de Processo Civil de 2015).

Outrossim, citado princípio são se restringe às partes e ao juiz, mas a todos os sujeitos que participam do processo. Nesse sentido, necessário se faz relembrar o texto do artigo $3 .^{\circ}, \S 3 .^{\circ}$, do Estatuto Processual: "A conciliação, a mediação e outros métodos de solução consensual de conflitos deverão ser estimulados por juízes, advogados, defensores públicos e membros do Ministério Público, inclusive no curso do processo judicial".

Ora, de se notar que tanto o artigo $3 .^{\circ}, \S 3 .^{\circ}$, quanto o artigo $6 .^{\circ}$, ambos da Lei Processual, utilizam o verbo "dever". Dessa maneira, considerando, por exemplo, os advogados, que a autocomposição é a melhor solução para o litígio, seja porque a matéria discutida tem divergência jurisprudencial, seja por qualquer outro motivo, é dever deles que orientem as partes nesse sentido.

Somado a isso, contrariando os posicionamentos citados, o Enunciado 373 do FPPC dispõe que: "As partes devem cooperar entre si; devem atuar com ética e lealdade, agindo de modo a evitar a ocorrência de vícios que extingam o processo sem resolução do mérito e cumprindo com os deveres mútuos de esclarecimento e transparência".

Rodrigo da Cunha Lima Freire e Maurício Ferreira Cunha, sobre o princípio da cooperação processual, elencam as seguintes regras de conduta ou deveres para todos os sujeitos do processo:

a) Dever de lealdade processual: as partes e o juiz não podem agir de má-fé (v.g., arts. 80; 81;142;143) ${ }^{26}$;

b) Dever de esclarecimento: o juiz deve esclarecer seus próprios pronunciamentos e, na mesma medida, pode exigir esclarecimentos das partes quanto às suas posições, alegações e pedidos (v.g., arts. $77, \S 1^{\circ}$; 321 , caput, parte final; 330, § $1^{\circ}$, II e V e 379, I) ${ }^{27}$;

\footnotetext{
${ }^{26}$ FREIRE, Rodrigo da Cunha Lima; CUNHA, Maurício Ferreira. Novo Código de Processo Civil para Concursos. $7^{\mathrm{a}}$ ed. Revista, ampliada e atualizada. Salvador: Editora JusPodivm, 2017. pp. 52-53. ${ }^{27}$ Ibidem.
} 
c) Dever de proteção: não se pode causar danos aos demais participantes do processo (v.g., arts. 77, VI; 448, I; 495, § 5; 520, I e IV; 521, parágrafo único; $525, \S 6^{\circ}$ e 776$)^{28}$;

d) Dever de prevenção: o juiz tem o dever de indicar as insuficiências, os defeitos e as irregularidades das postulações das partes, para que possam ser supridos, sanados ou superados (v.g., arts. 321 e 932, parágrafo único) ${ }^{29}$;

e) Dever de consulta: o juiz não pode resolver ou decidir questão ou matéria sobre a qual ainda não se pronunciou, sem a oitiva prévia das partes, ainda que a matéria seja cognoscível de ofício (v.g., arts. 10; 493, parágrafo único e 933) ${ }^{30}$.

Referidas regras ou deveres de conduta, conquanto não pareçam, estão intrinsicamente relacionadas ao tempo e ao prazo do processo. Exemplo clássico é a matéria que anteriormente poderia ser conhecida e decidida de ofício pelo juiz sem a oitiva prévia da parte. Com todo respeito à magistratura que possui conhecimento jurídico louvável, levar a questão às partes, a fim de que se pronunciem, pode evitar a interposição de recurso para sanar erro do juiz, gerando eventual nulidade e necessidade de repetição do ato $^{31}$.

Da mesma forma, propiciar que eventuais defeitos ou irregularidades sejam sanados pelas partes permite que o processo não seja extinto sem resolução de mérito, o que só produziria mais morosidade, posto que, evidentemente, outra ação seria proposta.

\section{CONSIDERAÇÕES FINAIS}

A Lei n. 13.105/15, por ser recente, tem sido objeto de inúmeras discussões doutrinárias, muitas das vezes com posicionamentos totalmente divergentes sobre um mesmo ponto. O presente trabalho se propôs a discutir acerca das controvérsias a respeito do prazo e do tempo razoáveis na busca da solução de mérito à luz do Código de Processo Civil de 2015, ante a divergência observada no tocante ao tema.

\footnotetext{
${ }^{28}$ FREIRE, Rodrigo da Cunha Lima; CUNHA, Maurício Ferreira. Novo Código de Processo Civil para Concursos. $7^{\mathrm{a}}$ ed. Revista, ampliada e atualizada. Salvador: Editora JusPodivm, 2017. pp. 52-53. ${ }^{29}$ Ibidem.

${ }^{30}$ Ibidem.

${ }^{31}$ Ibidem.
} 
Nesse contexto, é importante destacar que se trata de um tema vasto e um artigo científico, ainda que pautado em séria pesquisa, não poderia esgotá-lo.

O que se buscou, portanto, foi demonstrar que a novo sistema processual civil tem como base a primazia do julgamento de mérito e se as alterações entre a legislação processual de 1973 e 2015 trouxeram aspectos positivos ou negativos naquilo que diz respeito ao prazo e tempo processuais.

Em um primeiro momento, foram observados três pontos principais utilizados por aqueles que defendem que o Código de Processo Civil atual retroagiu, no aspecto pesquisado, em relação ao anterior. São eles: a) a contagem do prazo processual em dias úteis (artigo 219, caput, do Código de Processo Civil de 2015); b) a padronização do prazo recursal em 15 (quinze) dias - aumentando, por exemplo, o prazo para interposição de agravo de instrumento -, exceto os embargos de declaração (artigo 1.003, $\S 5 .^{\circ}$, do Código de Processo Civil de 2015); c) a suspensão do prazo processual nos dias compreendidos entre 20 de dezembro e 20 de janeiro, inclusive (artigo 220, caput, do Código de Processo Civil de 2015).

Referidos pontos, durante a pesquisa, foram facilmente rebatidos, restando evidente que o que traz morosidade na resolução de um litígio é o "tempo morto", isto é, o tempo mal utilizado entre os procedimentos.

Assim, o processo é moroso, não porque hoje se computa os prazos em dias úteis, porque o agravo de instrumento recebeu 05 (cinco) dias a mais ou porque há suspensão de prazos entre 20 (vinte) de dezembro e 20 (vinte) de janeiro, inclusive.

O processo é moroso, seja porque a máquina estatal não se encontra devidamente equipada, seja porque não há mecanismos de controle e gestão processual. Poder-se-ia acrescentar a (boa ou má) vontade de trabalhar do servidor público, mas referida afirmativa seria meramente empírica e sem embasamento científico, motivo pelo qual é melhor deixá-la de lado.

Não bastasse isso, a Lei Processual passou a estimular outras formas de resolução de conflitos, a exemplo da arbitragem, da conciliação e da mediação, as duas últimas, inclusive, no curso do processo. São meios alternativos que, além de desafogarem o Judiciário, podem chegar à resolução de mérito de forma justa e eficaz, dentro de um prazo não só razoável, mas verdadeiramente rápido. 
Contribuíram, para tanto, os CEJUSCs - Centros Judiciários de Solução de Conflitos e Cidadania -, que contam com o setor pré-processual, o setor processual e o setor de cidadania. Trata-se de verdadeira inovação por parte do Judiciário e que merece reconhecimento, muito embora em diversas comarcas tais centros não estejam instalados. Por meio de um mediador ou um conciliador devidamente capacitado, a depender do caso, uma demanda que poderia durar anos pode, em um ambiente mais informal e menos solene do que o fórum, ser resolvida em pouco tempo.

Somado a isso, não poderia este estudo deixar de abordar o princípio da cooperação processual até porque previsto expressamente no artigo $6 .^{\circ}$, da Lei Adjetiva. Referido princípio encontra-se longe de ter um entendimento pacífico. No entanto, de uma forma ou de outra, contribui, sem dúvidas, para a solução de mérito no processo.

Diante do que foi abordado, é possível observar que, de fato, há controvérsias a respeito da questão do prazo e do tempo razoáveis na busca da solução de mérito à luz do Código de Processo Civil de 2015, sobretudo no que diz respeito aos textos dos artigos $4 .^{\circ}$ e $6 .^{\circ}$, da Lei n. 13.105/15, vistos sob o prisma da sistemática processual.

Todavia, também foi possível concluir que a nova Lei Processual não trouxe qualquer prejuízo para o jurisdicionado no que diz respeito ao tema, abrindo-lhe um sistema multiportas para resolver seus litígios.

A verdade é que, independente do tempo e da forma de contagem dos prazos, aquele que tiver como objetivo criar óbice ao bom andamento processual continuará obtendo êxito, ante as brechas da lei. Afinal, qual o operador do Direito, pelo menos uma vez na vida, não obteve êxito em todos os procedimentos, inclusive recursais, porém não teve garantido o bem da vida, seja no sistema antigo, seja no novo. Somente aquele que realmente vive em um mundo paralelo, como citado no corpo do trabalho.

\section{REFERÊNCIAS}

BRASIL. Conselho Nacional de Justiça. Resolução No 125 de 29/11/2010. Disponível em: <http://www.cnj.jus.br/busca-atos-adm?documento=2579>. Acesso em 30 mai. 2018.

COELHO, Fábio Alexandre. Teoria Geral do Processo. Bauru: Livraria e Editora Spessotto, 2016.

DIDIER JR., Fredie. ZANETI JR., Hermes. Justiça multiportas e tutela constitucional adequada: autocomposição em direitos coletivos. Civil Procedure Review, v.7, n.3: 59-99, sept.-dec., 2016 ISSN 2191-1339 - Disponível em: www.civilprocedurereview.com Acesso em 01.06.2018. 
FREIRE, Rodrigo da Cunha Lima; CUNHA, Maurício Ferreira, Novo Código de Processo Civil para Concursos. $7^{\mathrm{a}}$ ed. Revista, ampliada e atualizada. Salvador: Editora JusPodivm, 2017.

MARINONI, Luiz Guilherme et al. Novo código de Processo Civil Comentado. 3. ed. São Paulo: Editora Revista dos Tribunais, 2017.

MOUZALAS, Rinaldo et al. Processo Civil. 9. ed. rev., ampl. e atual. Salvador: Ed. JusPodivm, 2017.

NERY JUNIOR, Nelson; NERY, Rosa Maria de Andrade. Código de Processo Civil Comentado. 16. ed. Ver., atual. e ampl.. São Paulo: Revista dos Tribunais, 2016.

NEVES, Daniel Amorim Assumpção. Novo Código de Processo Civil Comentado. 2. ed. rev. E atual. Salvador: Ed. Juspodivm, 2017.

OST, François. Júpiter, Hércules e Hermes: três modelos de Juez. Tradução de Isabel Lifante Vidal. In: DOXA - n.14, 1993, pp. 169-194. Disponível em: http://www.cervantesvirtual.com/...jpiterhrcules-y-hermes--tres-modelos-de-juez Acesso em 01.06.2018.

PACTO REPUBLICANO EM FAVOR DE UM JUDICIÁRIO MAIS RÁPIDO E REPUBLICANO, apelidado de Reforma do Judiciário encontra-se disponível no sítio http://www.stf.jus.br/por$\mathrm{tal} / \mathrm{cms} /$ verNoticiaDetalhe.asp?idConteudo=63995 Acesso reali-zado em 01.06.2018.

PINHO, Humberto Dalla Bernardina de. Direito Processual Civil Contempo-râneo: teoria geral do processo. 7Ed. São Paulo: Saraiva, 2017.

STRECK, Lenio Luiz. O que é isto - decido conforme minha consciência? 3.Ed. Porto Alegre: Livraria do Advogado, 2012.

Lenio Luiz; Nunes, Dirle; Cunha, Leonardo Carneiro da; Cunha, Lenoardo (orgs.). Comentários ao Código de Processo Civil. 2. ed. São Paulo: Saraiva, 2017. 